\title{
Analisis Komunikasi Sosial Media Twitter sebagai Saluran Layanan Pelanggan Provider Internet dan Seluler di Indonesia
}

\author{
Retno Agus Setiawan ${ }^{1)}$, Djoko Budiyanto Setyohadi ${ }^{2)}$ \\ ${ }^{1) 2)}$ Magister Teknik Informatika, Universitas Atma Jaya Yogyakarta \\ Jln. Babarsari No. 44, Yogyakarta 55281 \\ ${ }^{1)}$ retnoagussetiawan@gmail.com \\ ${ }^{2)}$ djoko@mail.uajy.ac.id
}

\begin{abstract}
Abstrak- Penggunaan sosial media sebagai layanan pelanggan memberikan banyak keuntungan bagi perusahaan. Pelanggan dapat menyampaikan keluhan, komentar, dan saran kepada perusahaan dengan mudah dan cepat. Namun tidak semua perusahaan yang menggunakan sosial media untuk meningkatkan layanan pelanggan memahami dengan baik interaksi yang terjadi yang melibatkan pelanggan. Penelitian ini mengidentifikasi interaksi yang terjadi antara pelanggan dan perusahaan melalui layanan pelanggan di lingkungan sosial media Twitter. Metode netnography digunakan untuk mengetahui bagaimana interaksi pelanggan dan perilaku perusahaan dalam berinteraksi. Hasil penelitian menunjukkan terdapat tiga kelompok utama interaksi pelanggan, yaitu keluhan $(42,20 \%)$, komentar $(35,55 \%)$ dan pertanyaan $(22,25 \%)$. Selain itu hasil penelitian menunjukkan perilaku perusahaan yang menggunakan pendekatan personal dan bersahabat dalam berinteraksi dengan pelanggan.
\end{abstract}

Kata Kunci-Layanan Pelanggan, Netnography, Sosial Media

Abstract - The use of social media as a customer service provides many advantages for the organizations. Customers can voice their complaints, comments, and suggestions to the organizations with easy and fast way. However, not all organizations that used social media to improve customer service understand about their interactions with customers. This study explores interactions that occur between customers and organization in Twitter environment. The netnography method is utilized to identify customer interactions and organizational behaviors. The results indicate that there are three types of customer interactions, complaints $(42.20 \%)$, comments $(35.55 \%)$ and questions $(22.25 \%)$. In addition, the organization uses personal and friendly approach to interact with customers.

Keywords-Customer Service, Netnography, Social Media

Article history:

Received 01 Februari 2017; Received in revised form 14 Maret 2017; Accepted 22 Maret 2017; Available online 28 April 2017

\section{Pendahuluan}

Perkembangan teknologi khususnya internet mengalami peningkatan yang sangat cepat. Di indonesia tercatat jumlah pengguna internet aktif mencapai 88,1 juta pengguna (Kemp, 2016). Internet memberikan sejumlah manfaat dan mengubah cara orang-orang dalam melihat informasi. Sejalan dengan internet, sosial media di Indonesia terus berkembang. Menurut Kemp (2016) jumlah pengguna aktif sosial media di Indonesia sekitar 79 juta pengguna. Sosial media berpotensi untuk terus berkembang dan menjadi bagian penting strategi perusahaan.

Sosial media adalah aplikasi web generasi kedua yang memungkinkan penciptaan jaringan online individu (Constantinides, Lorenzo-Romero, \& Alarcón-del-Amo, 2013). Lebih lanjut Hsu, Yu, \& Wu (2014) mengungkapkan sosial media memungkinkan pengguna untuk membangun jaringan sosial dan berinteraksi satu sama lain dalam lingkungan internet. Sosial media telah menjadi gaya hidup bagi semua orang di seluruh dunia.
Sosial media, salah satunya Twitter memberikan lingkungan baru dalam berinteraksi. Twitter berdiri sejak tahun 2006 dan telah digunakan secara luas. Saat ini sekitar 500 juta ulasan dikirimkan setiap harinya dan memiliki lebih dari 307 juta pengguna aktif (Internet Live Stats, 2017). Twitter dikenal sebagai layanan micro-blogging, memungkinkan penggunanya membaca, menulis, atau mengirimkan pesan pada forum umum.

Sosial media memberikan kemudahan dalam berkomunikasi dan memiliki kemampuan untuk menyajikan komunikasi dua arah (Fuchs et al., 2010). Hal tersebut memudahkan perusahaan untuk berinteraksi dengan pelanggan. Melalui sosial media perusahaan dapat berbagi informasi penting dengan pelanggan, menjaga hubungan baik dengan pelanggan, dan mendapatkan feedback dengan cara yang sangat mudah dan cepat.

Layanan pelanggan (customer service) merupakan bagian yang sangat penting dalam strategi bisnis. Layanan pelanggan memainkan peran strategis dalam meminimalkan masalah 
terkait dengan pelanggan. Layanan pelanggan merupakan aktivitas untuk meningkatkan tingkat kepuasan pelanggan sebelum, selama, atau setelah pembelian. Layanan pelanggan mengacu pada setiap layanan yang diberikan perusahaan kepada pelanggan untuk memenuhi kebutuhan mereka dan menjaga pelanggan tetap melekat pada perusahaan (Faed, 2013).

Penelitian ini mendefinisikan layanan pelanggan sebagai salah satu strategi perusahaan untuk tetap terhubung dengan pelanggan, memperoleh feedback dari pelanggan melalui komunikasi yang terjadi antara pelanggan dan perusahaan. Komunikasi yang baik merupakan kunci keberhasilan dari layanan pelanggan. Pelayanan yang tepat akan menentukan sikap pelanggan untuk tetap bertahan atau pergi meninggalkan perusahaan. Layanan pelanggan yang berhasil memungkinkan mengubah pelanggan yang sebelumnya tidak puas menjadi sangat puas karena perilaku teladan perusahaan (Garding \& Bruns, 2015b).

Layanan pelanggan memberikan kesempatan perusahaan untuk lebih dekat dengan pelanggan. Melalui layanan pelanggan perusahaan dapat mempelajari karakteristik pelanggan, mendapatkan informasi mengenai kelemahan dan kelebihan produk/layanan perusahaan. Lebih lanjut Scott et al (2011) menyatakan layanan pelanggan hadir karena alasan meningkatkan performa bisnis perusahaan. Dengan memperlakukan pelanggan dengan tingkat pelayanan yang tinggi akan mendorong kepuasan pelanggan. Kepuasan ini kemudian mendorong pelanggan untuk setia kepada perusahaan.

Penggunaan teknologi memungkinkan peningkatan efektifitas dalam pemulihan layanan. Seperti diungkapkan Fan et al (2010) saat ini interaksi manusia telah digantikan oleh teknologi layanan online. Layanan online seperti sosial media memberikan kesempatan pelanggan untuk menyampaikan keluhan secara mudah dan cepat (Ding \& Lii, 2016). Sosial media telah banyak digunakan perusahaan sebagai layanan pelanggan (Menne \& Halova 2013; Einwiller \& Steilen 2015).

Salah satu provider dan perusahaan telekomunikasi digital terdepan di Indonesia telah memanfaatkan penggunaan sosial media sebagai saluran layanan pelanggan. Dengan jumlah pelanggan mencapai 69,8 juta pelanggan, perusahaan selalu berusaha memberikan pelayanan terbaik kepada pelanggan. Di antaranya dengan menyediakan layanan pelanggan dengan beberapa pilihan saluran komunikasi. Salah satunya melalui akun resmi sosial media Twitter. Melalui akun resmi layanan pelanggan di Twitter, pelanggan dapat menyampaikan pertanyaan, keluhan, atau saran mengenai produk dan layanan yang diberikan oleh perusahaan.
Namun tidak semua perusahaan yang menggunakan sosial media untuk meningkatkan layanan pelanggan menggunakan teknik yang benar dan melakukannya dengan berhasil (Marketingprofs, 2012). Perusahaan seharusnya memperhatikan komunikasi yang terjadi sebelum memberikan tindakan pelayanan kepada pelanggan mengingat layanan yang diberikan akan mempengaruhi sikap dan tingkat kepuasan pelanggan. Selvanathan (2015) mengungkapkan adalah penting bagi perusahaan untuk menemukan cara yang tepat untuk memastikan pelanggan puas terhadap layanan yang diberikan.

Menne \& Halova (2013) berhasil mengidentifikasi perilaku pelanggan dalam menggunakan sosial media sebagai layanan pelanggan di industri penerbangan. Menne \& Halova percaya bahwa dengan memanfaatkan sosial media, perusahaan dapat melihat loyalitas pelanggan meningkat sebagai akibat dari peningkatan efisiensi. Dan dengan pendekatan yang tepat, pengalaman pelanggan dapat ditingkatkan.

Berdasarkan pembahasan masalah di atas penelitian ini telah membentuk pertanyaan penelitian utama yaitu 'Bagaimana komunikasi yang terjadi antara pelanggan dan perusahaan? Dan bagaimana perilaku perusahaan?'. Untuk menjawab pertanyaan penelitian di atas penelitian ini mengidentifikasi interaksi yang terjadi antara pelanggan dan perusahaan melalui layanan pelanggan. Penelitian ini mengumpulkan data berdasarkan interaksi yang terjadi melalui layanan pelanggan di media online Twitter.

Berbeda dengan Menne \& Halova (2013), penelitian ini mengidentifikasi interaksi melalui layanan pelanggan pada salah satu provider internet dan seluler di Indonesia. Netnography, dikembangkan oleh Kozinets (1998) merupakan metode penelitian untuk komunitas online, digunakan pada penelitian ini. Tujuan dari penelitian netnography ini adalah untuk mengamati bagaimana salah satu provider internet dan seluler di Indonesia berinteraksi dengan pelanggan melalui sosial media Twitter. Netnography dipilih karena sudah terbukti secara luas digunakan untuk mempelajari komunitas online (Kozinets 2010; Mkono 2012; Medberg \& Heinonen 2014; Wu \& Pearce 2014). Selain itu netnography lebih sederhana, cepat dan murah dibandingkan dengan teknik lainnya seperti etnography tradisional (Björk \& KauppinenRäisänen, 2012).

\section{LITERATUR REVIEW}

Ketertarikan bisnis terhadap sosial media terus meningkat sebagai sumber suara pelanggan dan informasi pasar. Constantinides et al (2013) mengungkapkan sosial media dapat digunakan sebagai alat untuk mengikat pelanggan, 
menciptakan interaksi sosial, dan membangun hubungan dengan pelanggan, dan juga sebagai media informasi, kolaborasi dan promosi. Peneliti mengungkapkan terdapat hubungan positif antara kemudahan sosial media dengan persepsi pengguna.

Penggunaan sosial media sebagai alat bisnis perusahaan menawarkan beberapa keuntungan bagi perusahaan (Seol, Lee, Yu, \& Zo, 2016). Diantaranya membantu perusahaan meningkatkan citra perusahaan dengan mengelola hubungan yang baik dengan pelanggan, sehingga meningkatkan penjualan dan mengurangi biaya untuk mempertahankan pelanggan. Keuntungan lain, perusahaan dapat dengan mudah berinteraksi dengan pelanggan melalui sosial media dan dapat membangun kepercayaan untuk berbagi layanan dengan pelanggan. Memiliki hubungan yang baik dengan pelanggan sangat membantu bagi perusahaan dalam banyak hal.

Selain beberapa keuntungan yang mungkin didapatkan, perusahaan juga harus mewaspadai dampak negatif yang mungkin diakibatkan dari penggunaan sosial media sebagai alat bisnis perusahaan. Salah satu dampak negatif yang bisa ditimbulkan adalah munculnya negative electronic word-of-mouth (negative eWOM). eWOM diartikan sebagai pertukaran informasi mengenai evaluasi produk atau jasa antara orang-orang di dunia virtual (King, Racherla, \& Bush, 2014). Kegagalan layanan pelanggan bisa berdampak buruk bagi perusahaan. Hal tersebut memungkinkan pelanggan mengirimkan komunikasi negatif terkait dengan perusahaan.

Lebih lanjut komunikasi negatif (negative eWOM) dapat mempengaruhi sikap dan niat membeli dari pelanggan dan berpotensi merusak citra perusahaan (Balaji, Khong, \& Chong, 2016). Secara khusus perasaan ketidakadilan dan atribut perusahaan mempengaruhi pelanggan mengirimkan komunikasi negatif di sosial media. Hal lain yang perlu diperhatikan adalah kemungkinan pesaing mengekploitasi komunikasi negatif untuk merusak reputasi perusahaan.

Pemulihan layanan yang berhasil dapat mencegah pelanggan dari penyebaran komunikasi negatif dan mempengaruhi niat membeli dari pelanggan (Ding \& Lii, 2016). Pemulihan layanan yang baik dapat membantu perusahaan mengubah situasi yang berpotensi negatif menjadi positif. Selain itu keberhasilan pemulihan layanan memungkinkan terjadinya peningkatan loyalitas pelanggan.

Garding \& Bruns (2015a) menganalisa kecukupan saluran pelanggan. Kecukupan saluran pelanggan penting untuk mendukung keberhasilan layanan pelanggan. Lima saluran komunikasi surat, email, telepon, tatap muka, dan sosial media dianalisis berdasarkan perspektif pelanggan. Hasil menunjukkan empat saluran tradisional (surat, email, telepon, tatap muka) dinilai lebih diterima untuk menyuarakan keluhan pelanggan. Selanjutnya sosial media memiliki potensi untuk merangkul generasi muda, untuk menyuarakan keluhan mereka terhadap perusahaan.

Selanjutnya Einwiller \& Steilen (2015) menganalisis bagaimana perusahaan skala besar menangani keluhan di halaman sosial media perusahaan. Diketahui bahwa tidak sepenuhnya perusahaan bersedia untuk berinteraksi melalui sosial media, perusahaan cenderung mengarahkan pelanggan menghubungi perusahaan melalui media lainnya, menghubungkan pelanggan kepada seseorang yang dapat memberikan solusi atas masalah yang disampaikan. Keluhan yang disampaikan sebagian besar terkait dengan produk atau layanan perusahaan. Dimana hampir setengahnya tidak mendapatkan respon perusahaan.

Menne \& Halova (2013) menguji bagaimana perusahaan memanfaatkan kekuatan dari integrasi sosial media dengan manajemen hubungan pelanggan (CRM) dalam rangka mempertahankan hubungan yang baik dengan pelanggan. Observasi dilakukan untuk melihat interaksi yang terjadi antara perusahaan dengan pelanggan di sosial media. Secara umum pelanggan memiliki perilaku positif terhadap perusahaan. Diketahui juga bahwa perusahaan memperlakukan pelanggan dengan pendekatan personal dan bersahabat. Dengan pendekatan customer-centric yang lebih dapat meningkatkan pengalaman pelanggan, meningkatkan layanan dan loyalitas pelanggan.

Menne \& Halova (2013) menggunakan teknik netnography untuk mengetahui interaksi yang terjadi di sosial media. Netnography diperkenalkan oleh Kozinets pada tahun 1998, merupakan adaptasi baru dari metode etnografi tradisional untuk lingkungan virtual internet dan dibuat secara khusus untuk menyelidiki perilaku komunitas yang hadir di internet (Kozinets, 1998, 2002). Dalam penggunaannya metode netnography sudah banyak diaplikasikan untuk penelitian media online (Xun \& Reynolds 2010; Mkono 2012; Wu \& Pearce 2014; Medberg \& Heinonen 2014; Aydin \& Alvarez 2016).

Lebih lanjut Kozinets (2010) menjelaskan bahwa netnography menggunakan komunikasi yang dimediasi oleh komputer sebagai sumber data dan merepresentasikan budaya dan kejadian umum lainnya. Pada bidang riset pasar dan konsumen netnography bertujuan untuk memahami keinginan, persepsi, sikap, pendapat dan perilaku konsumen dalam komunitas online (Bartl \& Tusche, 2016).

\section{MetodologI}

Netnography atau pengamatan secara online digunakan untuk melihat bagaimana interaksi antara perusahaan dan pelanggan berlangsung. 
Netnography adalah adaptasi dari etnography tradisional untuk internet sebagai lingkungan virtual (Kozinets, 2002). Netnography merupakan alat yang kuat untuk menyelidiki budaya perilaku individu dan masyarakat yang hadir di internet. Selain itu netnograpy hadir dengan cara yang lebih cepat dan mudah. Penelitian ini secara parsial mengikuti pedoman Kozinets (2002) meliputi beberapa tahapan seperti: entree, data collection, data analysis, data interpretation, dan member checks.

Tahap entree, mengidentifikasi komunitas online yang paling relevan untuk penelitian dan mempelajarinya untuk menjamin kesesuaian (Kozinets, 2002). Komunitas online bisa meliputi forum diskusi, blog, portal konsumen, chats room, dan platform lainnya yang dapat memberikan berbagai jenis informasi kepada peneliti (Kozinets, 2002; Bartl \& Tusche, 2016).

Tahap selanjutnya, data collection. Fase ini adalah tentang mengamati lebih dekat objek komunitas yang dipilih dan melakukan download informasi (Aydin \& Alvarez, 2016). Terdapat dua jenis pengumpulan data (Kozinets, 2002); Pertama, menyalin komunikasi antar partisipan di lingkungan online. Kedua, peneliti mencatat sendiri, menggambarkan aktivitas yang terjadi di lingkungan online. Penelitian ini mengadopsi pengumpulan data dengan melakukan download langsung informasi dari lingkungan online.

Tahap data analysis and interpretation, melakukan proses identifikasi, coding, dan mengelompokkan pola utama dalam data serta mengidentifikasi persamaan dan perbedaan interaksi. Tujuan dari tahap ini adalah untuk mencapai penjelasan tentang konsistensi dalam data (Kozinets, 2010).

Selanjutnya member checks, proses penyajian hasil penelitian kepada peserta penelitian dalam rangka untuk mendapatkan feedback (Kozinets, 2002). Member checks biasanya dilakukan setelah pengumpulan data dan analisis selesai dilakukan. Namun beberapa peneliti menentang perlunya menyajikan hasil penelitian kembali kepada peserta, terutama ketika penelitian netnography dilakukan secara diam-diam (Ismail, Melewar, \& Woodside, 2010), hal tersebut bukanlah pilihan untuk penelitian yang bersifat rahasia (Björk \& Kauppinen-Räisänen, 2012). Penelitian tipe ini tidak mengijinkan diskusi interaktif secara mendalam dengan anggota komunitas online (Kozinets, 2002). Pada penelitian ini tahap member checks tidak dilakukan, penelitian ini selesai sampai hasil analisis dan interpretasi data.

\section{HASIL DAN PEMBAHASAN}

Analisis temuan dari studi netnography terkait dengan komunikasi sosial media Twitter sebagai layanan pelanggan dibahas pada bagian di bawah ini:

\section{A. Entree: Mengidentifikasi Komunitas Online Yang Relevan}

Salah satu provider dan perusahaan telekomunikasi digital terbesar di Indonesia, dipilih untuk penelitian ini. Perusahaan yang berdiri sejak tahun 1967 dan berganti nama pada tahun 2015 ini mempunyai visi "Menjadi Perusahaan Telekomunikasi Digital Terdepan di Indonesia”. Dalam setiap kegiatan bisnisnya perusahaan selalu menjunjung tinggi nilai-nilai perusahaan, yaitu Terpercaya, Tekad menjadi yang terbaik, Cepat, dan Peduli. Lebih lanjut, salah satu misi perusahaan adalah fokus untuk "Memperlakukan Pelanggan sebagai Sahabat”.

Dalam rangka untuk menjangkau pelanggan, perusahaan menyediakan saluran layanan pelanggan melalui sosial media Twitter, dimana merupakan salah satu platform sosial yang paling banyak digunakan perusahaan untuk berinteraksi dengan pelanggan (Menne \& Halova, 2013). Akun resmi layanan pelanggan yang disediakan perusahaan memiliki sekitar 405.923 pengikut dengan jumlah tweet saat ini mencapai 1.336.079 dan berpotensi untuk terus bertambah. Perusahaan melalui micro-blogging Twitter secara konsisten melakukan interaksi melibatkan pelanggan.

\section{B. Data Collection: Mendownload Informasi Langsung Dari Sistem}

Pengumpulan data dilakukan selama periode tiga hari mulai dari 25-27 Desember 2016 dengan bantuan software NCapture for NVivo. Dalam melakukan pengumpulan data beberapa ulasan diabaikan dengan pertimbangan dapat mengakibatkan bias pada data seperti terdapat duplikasi data, link/gambar rusak, dan pertimbangan lainnya. Hasil akhir diperoleh sebanyak 508 tweet ulasan yang akan digunakan sebagai data primer untuk selanjutnya dilakukan analisis.

\section{Data Analysis And Interpretation: Identifikasi Pola Utama Dalam Data}

Analisis dari total 508 tweet diperoleh sebanyak 399 tweet merupakan ulasan dari pelanggan sedangkan sisanya 109 tweet merupakan ulasan dari perusahaan. Untuk menjawab pertanyaan penelitian 'Bagaimana komunikasi yang terjadi antara pelanggan dan perusahaan?', penelitian ini menggunakan pendekatan induktif, yaitu memeriksa data untuk menentukan dan mengklasifikasikan tema dan tren yang jelas dalam data (Obijiofor, 2015).

Lebih lanjut, penelitian ini mengikuti Aydin \& Alvarez (2016) melakukan analisis konten, proses identifikasi, skema koding dan pengkategorian data menggunakan perangkat lunak analisis data kualitatif QSR International's NVivo 11. Ulasan diklasifikasikan berdasarkan hasil pengamatan 
yang dilakukan secara berulang. Semua tweet ulasan telah dibaca beberapa kali untuk mendapatkan pandangan umum tema dalam data, kemudian mengembangkannya kedalam kategori berdasarkan kata kunci central (Mkono 2012; Medberg \& Heinonen 2014). Untuk memastikan validitas kategori penelitian ini mengklarifikasinya dengan melakukan peninjauan kembali data yang dilakukan secara terus menerus.

Hasil analisis menunjukkan terdapat beberapa karakteristik komunikasi yang terjadi antara pelanggan dan perusahaan.

\section{1) Interaksi Pelanggan}

Pengamatan dilakukan untuk menemukan tema dan kecenderungan dalam data. Berdasarkan hasil pengamatan, penelitian ini mengklasifikasikan interaksi pelanggan ke dalam tiga kategori utama yaitu keluhan, komentar, dan pertanyaan. Hal tersebut sejalan dengan Menne \& Halova (2013) yang memasukkan keluhan, komentar, dan pertanyaan sebagai hasil klasifikasi penelitian. Keluhan merepresentasikan ketidakpuasan pelanggan terhadap layanan atau produk perusahaan. Sedangkan komentar adalah bagaimana pelanggan menanggapi ataupun memberikan komentar terhadap produk atau layanan perusahaan. Pertanyaan mewakili perilaku pelanggan menanyakan hal yang berkaitan dengan produk atau layanan perusahaan.

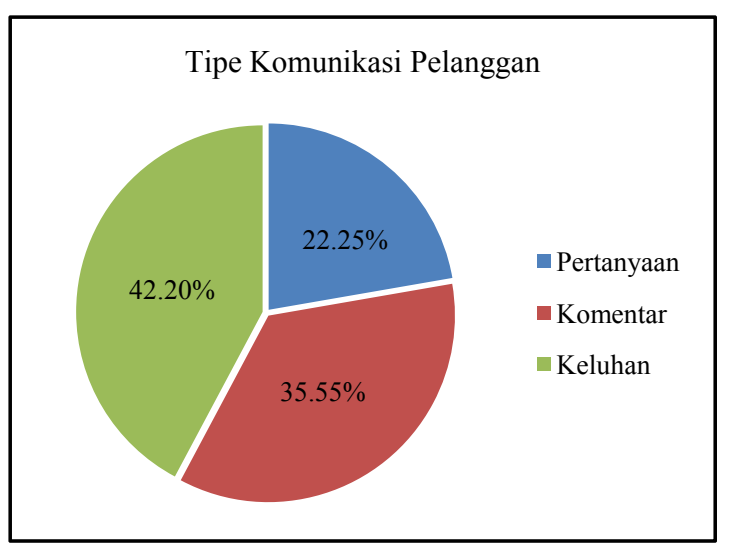

Gambar 1. Tipe komunikasi pelanggan

\section{a) Keluhan}

Keluhan melibatkan percakapan dimana pelanggan mengekspresikan ketidakpuasannya, rasa tidak suka, dan frustasi terhadap produk atau layanan perusahaan. Terdapat dua kemungkinan ketika pelanggan mendapatkan layanan atau produk diluar ekspektasi mereka, yaitu menyuarakan ketidakpuasan mereka ke perusahaan atau memilih diam dan berpotensi untuk meninggalkan perusahaan. Hasil analisis menyebutkan beberapa masalah yang dikeluhkan oleh pelanggan terhadap perusahaan, seperti ditunjukkan pada grafik berikut ini:



Gambar 2. Jenis keluhan pelanggan

Masalah jaringan adalah yang paling banyak dikeluhkan dengan prosentase 44,26\%. Salah satu pelanggan mengekspresikan ketidakpuasannya terhadap jaringan yang diberikan, dia mengatakan: "jaringan data provider anda di Ciamis sangatlah buruk, sinyal hanya dapat $H \& H+$ dengan gangguan setiap saat”. Pelanggan lainnya juga mengatakan hal yang sama "tolong dibantu ini $4 \mathrm{~g}$ dari siang ga konek, kumaha iyeu”.

Masalah lain yang dikeluhkan pelanggan adalah kecepatan mencapai 23,56\%. Sejumlah pelanggan mengungkapkan bahwa kecepatan yang mereka dapatkan tidak optimal. Seperti yang diungkapkan oleh salah satu pelanggan, dia mengatakan "Min ini gimana udah 1 mingguan speednya kok masih di limit sih, dan gak ada peningkatan sama sekali.!!’”.

Lebih lanjut jaringan dan kecepatan merupakan dua masalah dengan prosentase paling besar, diikuti paket $(9,20 \%)$, pulsa $(8,05 \%)$, panggilan $(5,75 \%)$, pesan $(5,17 \%)$, dan kuota dengan prosentase paling kecil $(4,02 \%)$. Sejalan dengan Einwiller \& Steilen (2015), hasil menunjukkan bahwa keluhan yang disampaikan sebagian besar terkait dengan produk atau layanan perusahaan.

\section{b) Komentar}

Komentar berisi percakapan pelanggan dalam menanggapi produk atau layanan perusahaan, berbagi konten gambar dan link dengan perusahaan, atau sekedar menyampaikan salam memperlihatkan bentuk kedekatan dengan perusahaan. Dalam memberikan komentarnya pelanggan memiliki karakteristik yang berbeda. Dalam penelitian ini menemukan bahwa terdapat dua karakteristik pelanggan dalam menyampaikan komentar.

Sebanyak $10,53 \%$ pelanggan memberikan komentar dengan menggunakan pilihan kata positif seperti mengucapkan salam 'hai', 'pagi', dan ucapan 'terima kasih', bahkan tidak sedikit mereka memberikan pujian terhadap layanan yang telah diberikan, seperti yang dikatakan oleh salah satu pelanggan "Terima kasih. Responnya cepat dan solutif'. Pelanggan lain memilih menyampaikan komentar dengan memberikan sedikit candaan “ 
iyaaaa makasih. Mudah mudahan jaringannya cpt luas. Seluas samudra huhi". Hal tersebut membuat komentar mereka lebih mudah diterima oleh perusahaan.

Namun tidak semua pelanggan memilih pilihan kata positif dalam menyampaikan komentar, terdapat $3,51 \%$ pelanggan menyampaikan komentar menggunakan pilihan kata atau bahasa yang sulit untuk diterima, bahkan sebagian dari mereka memberikan hujatan kepada perusahaan. Seperti ditunjukkan oleh salah satu tweet pelanggan yang mengatakan "kalo ngomong doang mah gampang bos! Kenyataannya lu tu bapuk!’. Pelanggan lain juga menyampaikan kekecewaannya, dia mengatakan "Luar biasa sekali ngecewainnya! T.O.P pokoknya mah. Operator2nya pada waras ga si? Masih pada idup kan?". Lebih lanjut, pemilihan penggunaan kata atau kalimat sangat bergantung pada motivasi pelanggan dalam mengirimkan komentar.

\section{c) Pertanyaan}

Sebanyak 22,55\% pelanggan mengirimkan pertanyaan ditujukan untuk perusahaan. Berawal dari minimnya informasi, pelanggan mengirimkan pertanyaan mulai dari lokasi gerai, promo ataupun pertanyaan lain mengenai produk atau layanan perusahaan. Berikut contoh pertanyaan yang dikirimkan pelanggan kepada perusahaan melalui twitter "Hai Kak, apakah promo 1 bulan Spotify Premium dan 3 bulan Iflix masih berlaku untuk pembelian perdana? Tks". Pelanggan tersebut menanyakan promo yang ditawarkan perusahaan. Promo lain yang juga ditanyakan oleh pelanggan adalah promo sms, seperti ditunjukkan pada tweet berikut "Min..Apa promo sms sekali gratis $950+$ 50 ke opr lain sdh gak berlaku yah..??”.

Pertanyaan mengenai paket yang ditawarkan merupakan jenis pertanyaan yang paling banyak diajukan mencapai 18,39\%. Berikut adalah salah satu pertanyaan yang diajukan pelanggan mengenai paket internet, "slmt malam, sy ingin tanyakan paket internet utk hp $3 g$. Brp harganya yg untuk 3gb/bln? Terima kasih”. Pelanggan lain juga menanyakan mengenai paket lainnya seperti pada tweet berikut "cara berhenti paket freedom gimana ya ?". Dengan munculnya banyak pertanyaan mengenai produk atau layanan yang ditawarkan, seharusnya perusahaan lebih meningkatkan sosialisasi produk atau layanan mereka kepada pelanggan.

Pertanyaan menarik muncul dari salah satu pelanggan, dia mengatakan "mau tanya dong twitternya kak lina apa?". Perlu diketahui bahwa Lina merupakan nama salah satu petugas yang bertugas melayani pelanggan. Pelanggan tersebut memberikan pertanyaan diluar konteks produk atau layanan yang diberikan. Dari pertanyaan yang diajukan memperlihatkan kedekatan yang terjalin antara pelanggan dan perusahaan.
Dari hasil pengamatan di atas, seperti ditunjukkan Gambar 1, diketahui keluhan memperoleh prosentase paling besar mencapai $42,20 \%$, diikuti komentar $35,55 \%$ dan pertanyaan 22,25\%. Keluhan adalah ekpresi ketidakpuasan tentang kesalahan sebuah organisasi/perusahaan (Einwiller \& Steilen, 2015). Namun, tidak semua keluhan memiliki arti negatif bagi perusahaan. Sebaliknya, jumlah keluhan yang sedikit harus dilihat sebagai peringatan awal bagi perusahaan. Ketidakhadiran keluhan akan membuat perusahaan semakin sulit untuk mengetahui kapan dan mengapa pelanggan merasa tidak puas. Perusahaan harus memfasilitasi masalah keluhan dan menghadirkan manajemen keluhan yang baik sehingga menghasilkan rasa puas bagi pelanggan (Garín-Muñoz, Pérez-Amaral, Gijón, \& López, 2016).

Lebih lanjut, keluhan pelanggan memberikan kesempatan kepada perusahaan untuk mempelajari masalah yang ada dan mengambil keputusan korektif yang tepat untuk memastikan bahwa kesalahan tidak berulang (Namkung, Jang, \& Choi, 2011). Pelanggan mungkin masih akan menyuarakan keluhannya jika mereka beranggapan bahwa perusahaan akan membantunya (Einwiller \& Steilen, 2015). Hingga pada akhirnya kepuasan pelanggan ada di tangan perusahaan yang harus menemukan cara yang tepat untuk memastikan pelanggan puas dengan pelayanan yang diberikan (Selvanathan, 2015).

Pada media online seperti Twitter, keluhan dapat menjadi publik dan dapat merusak reputasi sebuah organisasi. Perusahaan selaku penyedia layanan diharapkan mendengarkan setiap masukan informasi dan segera membenahi layanan yang diberikan. Pemulihan layanan yang baik akan mempengaruhi niat membeli dari pelanggan dan menghindarkan dari komunikasi negative (Ding \& Lii, 2016). Dengan pelayanan yang berhasil perusahaan memiliki kesempatan untuk merubah kondisi menjadi lebih baik dan memungkinkan untuk meningkatkan retensi dan loyalitas pelanggan.

Menanggapi masukan seperti komentar, pertanyaan, dan bahkan keluhan yang ditujukan ke perusahaan seharusnya dapat ditangani dengan pendekatan yang tepat. Salah sedikit saja dalam menanggapinya bisa berakibat pada ketidakpuasan pelanggan dan kemungkinan untuk ditinggalkan. Saat terjadi masalah, perusahaan harus mempercepat pemulihan layanan untuk memenuhi harapan pelanggan. Selain itu komunikasi yang baik harus tetap terjaga demi meningkatkan kualitas hubungan dengan pelanggan. Memiliki hubungan yang baik dengan pelanggan sangat membantu bagi perusahaan dalam banyak hal (Seol et al., 2016). 


\section{2) Ekspresi Pelanggan}

Setiap pelanggan mempunyai cara yang berbeda dalam mengekspresikan kepuasan / ketidakpuasannya terhadap produk atau layanan yang diberikan oleh perusahaan penyedia layanan selular dan internet. Dari 399 tweet yang berasal dari pelanggan terdapat sekitar 53,13\% pelanggan mengungkapkan kepuasan / ketidakpuasan mereka dalam bentuk ekpresi. Ekspresi bisa berupa penggunaan kata atau frase tertentu yang merepresentasikan perasaan pelanggan pada saat menyampaikan suara mereka kepada perusahaan melalui media Twitter.

Sebanyak 39,85\% menggunakan frase positif untuk merepresentasikan perasaan mereka. Ketika pelanggan meminta bantuan, mereka menyisipkan frase 'mohon' atau 'tolong' dengan harapan mendapatkan respon yang baik dari perusahaan. Tidak sedikit pula pelanggan yang menggunakan kata sapaan ' $k a k$ ' dan ' $m i n$ ' dalam menyampaikan suara mereka. Hal tersebut membuat interaksi menjadi lebih bersahabat. Tidak lupa diakhir kalimat mereka menggunakan ucapan 'terima kasih', 'thanks', dan sejenisnya sebagai ungkapan terima kasih.

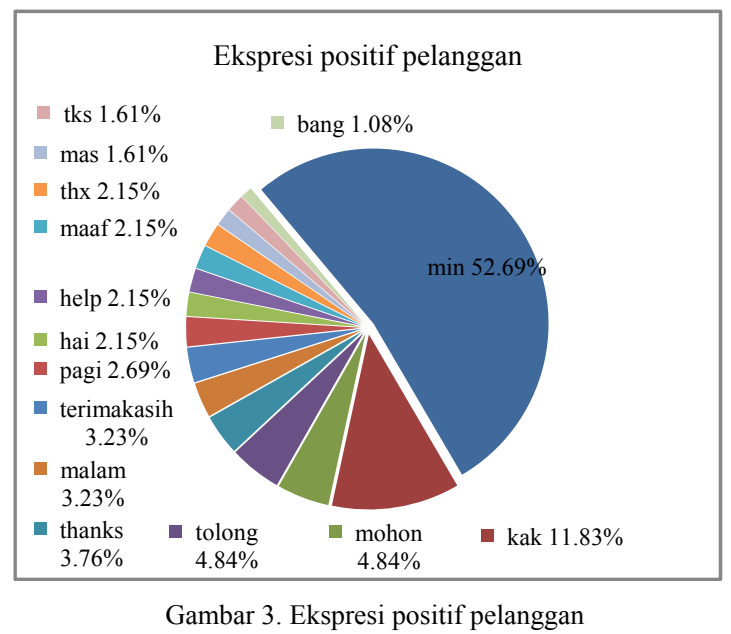

Sedangkan $13,53 \%$ pelanggan mengungkapkan ekspresi mereka dengan penggunaan frase yang bersifat negatif. Penggunaan frase negatif cenderung menggambarkan ketidakpuasan pelanggan terhadap produk atau layanan perusahaan. Frase negatif 'bapuk', 'busuk', 'anjing' dipilih karena frase tersebut dianggap dapat mewakili perasaan pelanggan pada saat menyuarakan suara mereka kepada perusahaan.

Seperti ditunjukkan pada tweet berikut ini, beberapa pelanggan menyatakan ketidakpuasan mereka kepada perusahaan, salah satu pelanggan mengatakan “@always_ero usahakan apa goblok 1 minggu usaha ? Keburu habis durasi paket". Pelanggan lain juga menyatakan hal yang sama, "@hailohai96 kepadatan jaringan kyk gmn idiot? Udh 2 minggu”. Lebih jauh lagi salah satu pelanggan mengungkapkan kemarahannya kepada perusahaan, dia mengatakan “@YFR013 pembodohan bilang aja anjing sengaja sekali nanya tdi gk dibalas mau kabur tanggung jawab".



Gambar 4. Ekspresi negatif pelanggan

Ketidakpuasan pelanggan dapat berakibat pada munculnya komunikasi negatif yang berpotensi membuat citra buruk perusahaan (Balaji et al., 2016), dan juga dapat mempengaruhi sikap dan niat membeli dari pelanggan. Pelanggan yang tidak puas cenderung untuk memberitahu orang lain tentang ketidaksukaan mereka terhadap perusahaan. Selain itu pelanggan dapat mempublikasikan komunikasi yang merugikan perusahaan dan beberapa mungkin akan beralih ke pesaing.

Penggunaan sosial media memungkinkan terjadinya penyebaran informasi secara publik, baik positif (positive WOM) maupun negatif (negative WOM). Informasi positif dibangun berdasarkan evaluasi rasional, sedangkan informasi negatif lebih didorong oleh emosi yang kuat seperti kemarahan, frustasi dan putus asa. Lebih lanjut informasi positif terutama didorong oleh kualitas layanan, sedangkan informasi negatif mencerminkan ketidakpuasan terhadap layanan. Meskipun informasi negatif dapat dengan mudah menyebar dan merusak citra perusahaan, namun dampak informasi negatif tidak sekuat manfaat dari informasi positif (Adjei, Noble, \& Noble, 2010).

Dalam kasus penggunaan informasi negatif ini, perusahaan seharusnya memberikan penanganan khusus kepada pelanggan dengan pendekatan yang lebih baik sehingga diharapkan bisa memperbaiki hubungan dengan pelanggan dan meningkatkan kepuasan pelanggan. Dengan meningkatnya kepuasan memungkinkan pelanggan menyebarkan informasi positif yang tentu saja dapat meningkatkan citra perusahaan, mengingat sosial media Twitter bersifat publik sehingga semua ulasan dapat diakses dan dibaca oleh siapapun. Itu adalah publisitas gratis untuk perusahaan (Menne \& Halova, 2013).

\section{3) Perilaku Perusahaan}

Sebanyak 109 tweet ulasan oleh perusahaan dianalisis untuk menjawab pertanyaan penelitian tentang perilaku dan pola interaksi perusahaan. 


\section{sahabat}

a) Memperlakukan pelanggan sebagai

Seperti disebutkan sebelumnya, salah satu misi perusahaan adalah "memperlakukan pelanggan sebagai sahabat”. Tampaknya perusahaan sudah benar-benar mampu melakukannya melalui cara mereka berinteraksi dengan pelanggan. Penelitian ini menemukan bahwa perusahaan sebagai provider internet dan seluler ini sudah menciptakan komunikasi yang lebih bersahabat dan personal dalam setiap pelayanan yang diberikan. Hal tersebut terlihat dari penggunaan kata 'hai', 'kak', 'thanks' (lihat Gambar 5) yang digunakan perusahaan dalam berinteraksi dengan pelanggan.

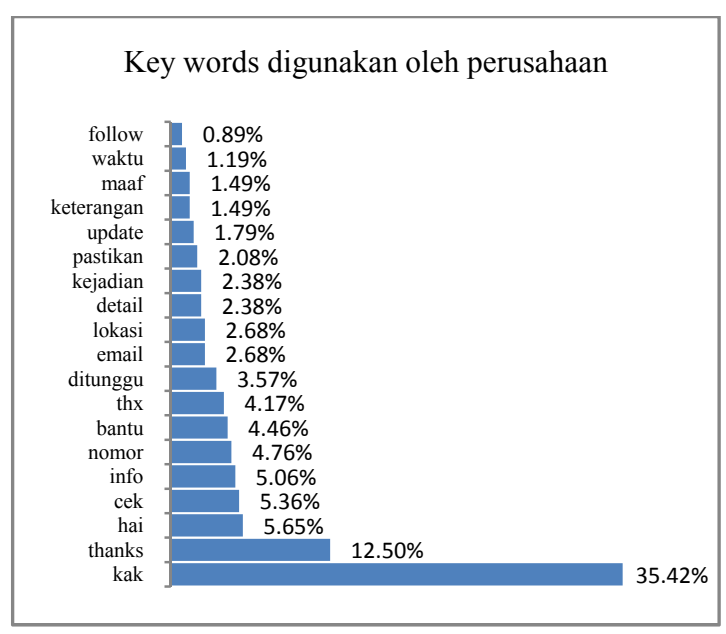

Gambar 5. Key words digunakan oleh perusahaan

Dengan sikap teladan perusahaan dapat mengubah perilaku pelanggan yang semula tidak puas menjadi sangat puas (Garding \& Bruns, 2015b). Hasil penelitian ini sejalan dengan Menne \& Halova (2013), perusahaan memperlakukan pelanggan dengan pendekatan personal dan bersahabat dengan maksud meningkatkan pengalaman pelanggan, meningkatkan layanan dan loyalitas pelanggan. Hasil penelitian ini sekaligus membantah Einwiller \& Steilen (2015) yang menyebutkan bahwa perusahaan kurang bersedia untuk berinteraksi dengan pelanggan.

\section{b) Nilai-nilai perusahaan}

Berikut adalah beberapa nilai yang dimiliki oleh perusahaan:

- Terpercaya

Berpikir positif, konsisten dalam perkataan dan perbuatan yang terpuji serta dapat diandalkan.

- Tekad menjadi yang terbaik

Semangat mencapai keunggulan dengan melakukan perbaikan dan penyempurnaan berkesinambungan.

- Cepat

Sigap dalam memecahkan masalah, mengambil keputusan, bertindak dan beradaptasi
- $\quad$ Berjiwa muda

Enerjik, dinamis, dan berani menjadi penggerak perubahan

- Peduli

Menunjukkan perhatian, menghargai, serta melayani sepenuh hati.

Beberapa interaksi perusahaan dengan pelanggan memperlihatkan adanya penerapan nilai-nilai yang dimiliki perusahaan. Perusahaan dalam berinteraksi dengan pelanggan secara konsisten melakukan pendekatan secara personal dan bersahabat. Lebih lanjut, kedekatan dengan pelanggan menjadi hal yang penting bagi perusahaan.

Beberapa ulasan mengungkapkan bahwa perusahaan berusaha berinteraksi dengan pelanggan untuk menunjukkan bahwa perusahaan peduli kepada mereka, tentang pendapat dan masalah mereka. Seperti ditunjukkan pada ulasan "Kak, bisa infokan detail kesulitannya ya, kita bantu cek. Thx ^Kiki”. Selain itu dalam beberapa hal perusahaan memberikan balasan dalam nada yang sama dengan apa yang disampaikan pelanggan. Jika pelanggan menggunakan nada yang serius dan resmi, perusahaan akan memberikan jawaban dengan nada yang sama. Demikian juga, jika pelanggan merasa gembira dengan layanannya perusahaan akan meresponnya dengan nada gembira. Seperti terlihat pada ulasan berikut "Okey kak, sama-sama, have a nice weekend ya. Tq ${ }^{\wedge} \mathrm{Nia}$ ”.

Hingga pada akhirnya perusahaan berusaha menunjukkan bahwa mereka menghargai komentar, saran, dan pendapat pelanggan. Perusahaan menyampaikan "Maaf atas ketidaknyamanannya" untuk menunjukkan sikap empati kepada pelanggan. Dalam banyak kasus permintaan maaf adalah hal yang diinginkan oleh pelanggan (Garín-Muñoz et al., 2016). Selain itu perusahaan selalu memanggil " $k a k$ " dan mengatakan "thanks" untuk menghargai tanggapan yang diberikan pelanggan. Berterima kasih kepada pelanggan akan membuat pelangan merasa dihargai dan berdampak pada meningkatkan kepuasan pelanggan (Einwiller \& Steilen, 2015). Dalam kasus lain ketika pelanggan menyampaikan komentar, saran, dan pendapatnya perusahaan mencoba untuk menunjukkan bahwa pendapat mereka adalah penting, perusahaan akan melakukan pengecekan lebih lanjut "kita cek dulu $y a^{\prime \prime}$.

Sejauh ini perusahaan sudah menunjukkan pengelolaan layanan pelanggan yang baik. Namun, hal tersebut harus terus ditingkatkan untuk meningkatkan kepuasan dan loyalitas pelanggan. Terutama dalam menanggapi setiap keluhan dari pelanggan. Menanggapi keluhan yang disuarakan pelanggan melalui sosial media sampai membuatnya puas adalah hal yang penting 
mengingat sosial media bersifat publik dan dapat diakses oleh siapapun (Einwiller \& Steilen, 2015).

Garín-Muñoz et al (2016) merekomendasikan beberapa hal yang harus dilakukan dalam menanggapi keluhan sebagai upaya untuk memaksimalkan kepuasan pelanggan. Beberapa di antaranya adalah:

- Dengarkan apa yang dikatakan pelanggan.

- Meminta maaf.

- Cari tahu apa yang dapat dilakukan untuk memperbaiki situasi.

- Bersiaplah untuk melatih staf dalam penanganan keluhan, dan menyetujui bahwa masalah pelanggan adalah prioritas

- Ingat bahwa, jika Anda mendapatkan respon yang tepat, pelanggan akan puas dan akan datang kembali untuk membeli lagi.

- Catat detail keluhan dan selidiki mengapa produk/jasa gagal.

Dengan menggunakan rekomendasi di atas, penyedia layanan dapat meningkatkan kepuasan pelanggan dengan penanganan keluhan, dan dengan demikian meningkatkan kepuasan secara keseluruhan (Garín-Muñoz et al., 2016). Lebih lanjut, Persepsi positif dari upaya pemulihan layanan tidak hanya menghasilkan pelanggan yang puas dan percaya, tetapi juga menghasilkan komunikasi positif tentang pengalaman layanan serta mendorong pelanggan untuk terus menggunakan layanan (Ding \& Lii, 2016).

\section{KESIMPULAN}

Penelitian ini melakukan analisis komunikasi sosial media Twitter sebagai layanan pelanggan pada salah satu provider internet dan seluler di Indonesia. Tujuan utama dari penelitian ini adalah untuk mengetahui bagaimana interaksi yang terjadi antara perusahaan dan pelanggan, serta perilaku perusahaan dalam berinteraksi dengan pelanggan. Analisis fokus pada interaksi yang terjadi melalui layanan pelanggan di sosial media Twitter. Penelitian ini memberikan konstribusi membantu perusahaan mengetahui interaksi yang terjadi melalui layanan pelanggan di lingkungan sosial media Twitter. Selain itu penelitian ini mengkonfirmasi penggunaan netnography dalam penelitian komunitas online, khususnya miscroblogging Twitter.

Hasil penelitian mengungkapkan terdapat tiga kelompok utama interaksi pelanggan meliputi keluhan, komentar, dan pertanyaan. Interaksi keluhan memiliki prosentase paling besar mencapai $42,20 \%$ diikuti komentar $35,55 \%$ dan pertanyaan $22,25 \%$. Untuk dapat meningkatkan nilai kompetisi perusahaan harus segera memperbaiki layanan yang diberikan, terutama masalah jaringan dan kecepatan yang merupakan masalah yang paling banyak dikeluhkan. Selain itu, berkaitan dengan banyaknya keluhan yang disuarakan perusahaan perlu menciptakan manajemen keluhan yang baik untuk memaksimalkan kepuasan pelanggan.

Secara umum sebagian besar pelanggan $(53,13 \%) \quad$ mengungkapkan kepuasaan /ketidakpuasannya dalam bentuk ekspresi. Ekspresi positif didasarkan pada evaluasi rasional tentang kualitas layanan, sedangkan ekspresi negatif lebih didorong oleh ketidakpuasan terhadap layanan yang diterima pelanggan. Tercatat sedikitnya $13,53 \%$ pelanggan menggunakan ekpresi negatif.

Temuan lainnya mengungkapkan perilaku perusahaan dalam berinteraksi dengan pelanggan. Secara konsisten perusahaan menggunakan pendekatan secara personal dan bersahabat ketika berkomunikasi dengan pelanggan. Selain itu dalam beberapa kasus perusahaan berusaha mengedepankan nilai-nilai perusahaan dalam berinteraksi dengan pelanggan. Perusahaan berusaha untuk senantiasa menghargai setiap masukan yang diberikan oleh pelanggan. Hal tersebut baik untuk pelanggan maupun perusahaan untuk meningkatkan kualitas hubungan yang lebih baik sehingga diharapkan dapat meningkatkan kepuasan pelanggan dan citra baik perusahaan.

Lebih lanjut, penelitian ini melakukan analisis terbatas hanya pada layanan pelanggan sosial media Twitter pada salah satu provider internet dan seluler di Indonesia. Ini berarti hasil temuan bersifat spesifik pada lingkungan tertentu dan hasil temuan mungkin tidak dapat digeneralisasikan untuk lingkungan lainnya. Oleh karena itu, studi dalam lingkungan berbeda dan konteks yang bervariasi direkomendasikan.

\section{DAFTAR PUSTAKA}

Adjei, M. T., Noble, S. M., \& Noble, C. H. (2010). The influence of $\mathrm{C} 2 \mathrm{C}$ communications in online brand communities on customer purchase behavior. Journal of the Academy of Marketing Science, 38(5), 634-653.

Aydin, B., \& Alvarez, M. D. (2016). English-Speaking Tourists' Evaluation of Sustainability Attributes in Cultural Tourism Destinations: The Case of Cusco. Teorija in Praksa, 53(4), 942-958,1024.

Balaji, M. S., Khong, K. W., \& Chong, A. Y. L. (2016). Determinants of negative word-of-mouth communication using social networking sites. Information \& Management, 53(4), 528-540.

Bartl, M., \& Tusche, N. (2016). Netnography: The Mint Journey. In R. Egger, I. Gula, \& D. Walcher (Eds.), Open Tourism: Open Innovation, Crowdsourcing and Co-Creation Challenging the Tourism Industry. inbook, Berlin, Heidelberg: Springer Berlin Heidelberg.

Björk, P., \& Kauppinen-Räisänen, H. (2012). A Netnographic Examination Of Travelers' Online Discussions Of Risks. Tourism Management Perspectives, 2-3, 65-71.

Constantinides, E., Lorenzo-Romero, C., \& Alarcóndel-Amo, M.-C. (2013). Social Networking Sites as Business Tool: A Study of User Behavior BT 
- Business Process Management: Theory and Applications. In M. Glykas (Ed.), CHAP, Berlin, Heidelberg: Springer Berlin Heidelberg.

Ding, M.-C., \& Lii, Y.-S. (2016). Handling online service recovery: Effects Of Perceived Justice On Online Games. Telematics and Informatics. 33(4). 881-895.

Einwiller, S. A., \& Steilen, S. (2015). Handling complaints on social network sites - An analysis of complaints and complaint responses on Facebook and Twitter pages of large \{US \} companies. Public Relations Review, 41(2), 195204.

Faed, A. (2013). Solution Overview. In An Intelligent Customer Complaint Management System with Application to the Transport and Logistics Industry. inbook, Heidelberg: Springer International Publishing.

Fan, Y.-W., Wu, C.-C., \& Wu, W.-T. (2010). The Impacts Of Online Retailing Service Recovery And Perceived Justice On Consumer Loyalty. International Journal of Electronic Business Management, 8(3), 239-249.

Fuchs, C., Hofkirchner, W., Schafranek, M., Raffl, C., Sandoval, M., \& Bichler, R. (2010). Theoretical Foundations of the Web: Cognition, Communication, and Co-Operation. Towards an Understanding of Web 1.0, 2.0, 3.0. Future Internet, 2(1), 41-59.

Garding, S., \& Bruns, A. (2015). Analysis of Customers' Complaint Channel Choice and Complaint Behaviour. In Complaint Management and Channel Choice: An Analysis of Customer Perceptions. inbook, Cham: Springer International Publishing.

Garding, S., \& Bruns, A. (2015). Organisational Complaint Management. In Complaint Management and Channel Choice: An Analysis of Customer Perceptions. inbook, Cham: Springer International Publishing.

Garín-Muñoz, T., Pérez-Amaral, T., Gijón, C., \& López, R. (2016). Consumer Complaint Behaviour In Telecommunications: The Case Of Mobile Phone Users In Spain. Telecommunications Policy, 40(8), 804-820.

Hsu, C.-L., Yu, C.-C., \& Wu, C.-C. (2014). Exploring The Continuance Intention Of Social Networking Websites: An Empirical Research. Information Systems and E-Business Management, 12(2), 139-163

Internet Live Stats. (2017). Twitter Usage Statistics. Retrieved March 3, 2017, from http://www.internetlivestats.com/

Ismail, A., Melewar, T., \& Woodside, A. (2010). A Netnography Study To Uncover The Underlying Dimensions Of Customer Experience With Resort Brands. Brunel Business School Research Papers, 1-51. Retrieved from http://bura.brunel.ac.uk/handle/2438/4277

Kemp, S. (2016). Digital in 2016. Retrieved April 16, 2016, from http://wearesocial.com/sg/specialreports/digital-2016

King, R. A., Racherla, P., \& Bush, V. D. (2014). What We Know and Don't Know About Online Wordof-Mouth: A Review and Synthesis of the Literature. Journal of Interactive Marketing, 28(3), 167-183
Kozinets, R. V. (1998). On netnography: Initial reflections on consumer research investigations of cyberculture. NA-Advances in Consumer Research Volume 25

Kozinets, R. V. (2002). The Field Behind the Screen: Using Netnography for Marketing Research in Online Communities. Journal of Marketing Research, 39(1), 61-72

Kozinets, R. V. (2010). Netnography: Doing Ethnographic Research Online. incollection, Sage Publications Ltd.

Lewis, B. R. (1995). Customer Care And Service Quality. In C. Ennew, T. Watkins, \& M. Wright (Eds.). Marketing Financial Services. $2^{\text {nd }}$ Edision. incollection, Oxford: ButterworthHeinemann.

Marketingprofs. (2012). Top Brands Using Twitter for Customer Support. Retrieved March 3, 2017, from

https:/www.marketingprofs.com/login/join?sour $\mathrm{ce}=/$ charts/2012/9654/top-brands-using-twitterfor-customer-support

Medberg, G., \& Heinonen, K. (2014). Invisible value formation: A netnography in retail banking. The International Journal of Bank Marketing, 32(6), 590-607

Menne, R., \& Halova, D. (2013). Using Social CRM to influence Customer Service and Loyalty: A Perspective in the Airline Industry (Master's thesis). Lund University.

Mkono, M. (2012). A netnographic examination of constructive authenticity in Victoria Falls tourist (restaurant) experiences. International Journal of Hospitality Management, 31(2), 387-394

Namkung, Y., Jang, S. (Shawn), \& Choi, S. K. (2011). Customer complaints in restaurants: Do they differ by service stages and loyalty levels? International Journal of Hospitality Management, 30(3), 495-502.

Obijiofor, L. (2015). Ethnographic Research in 'Offline' and Online Worlds. In New Technologies in Developing Societies: From Theory to Practice. inbook, London: Palgrave Macmillan UK.

Scott, C., Lundgren, H., \& Thompson, P. (2011). Guide to Customer Service in Supply Chain Management. In Guide to Supply Chain Management. inbook, Berlin, Heidelberg: Springer Berlin Heidelberg.

Selvanathan, M. (2015). The Effects of Employees' Attitude on Excellent Work Quality among Malaysian Government Employees towards Customers' Satisfaction. Global Management Journal, 7(1/2), 14-26.

Seol, S., Lee, H., Yu, J., \& Zo, H. (2016). Continuance usage of corporate $\{\mathrm{SNS}\}$ pages: A communicative ecology perspective. Information \& Management

Wu, M.-Y., \& Pearce, P. L. (2014). Chinese recreational vehicle users in Australia: A netnographic study of tourist motivation. Tourism Management, 43, 22-35

Xun, J., \& Reynolds, J. (2010). Applying netnography to market research: The case of the online forum. Journal of Targeting, Measurement and Analysis for Marketing, 18(1), 17-31 